\title{
Ozone distributions over southern Lake Michigan: comparisons between ferry-based observations, shoreline-based DOAS observations and model forecasts
}

\author{
P. A. Cleary ${ }^{1}$, N. Fuhrman ${ }^{1}$, L. Schulz ${ }^{2, *}$, J. Schafer ${ }^{3}$, J. Fillingham ${ }^{3}$, H. Bootsma ${ }^{3}$, J. McQueen ${ }^{4}$, Y. Tang ${ }^{4, * *}$, \\ T. Langel ${ }^{5}$, S. McKeen ${ }^{6}$, E. J. Williams ${ }^{5,6}$, and S. S. Brown ${ }^{5}$ \\ ${ }^{1}$ University of Wisconsin-Eau Claire, Department of Chemistry, 105 Garfield Ave, Eau Claire, WI 54702, USA \\ ${ }^{2}$ University of Wisconsin-Parkside, 900 Wood Road, Kenosha, WI 53144, USA \\ ${ }^{3}$ University of Wisconsin-Milwaukee, School of Freshwater Science, 600 E Greenfield Ave, \\ Milwaukee, WI 53204, USA \\ ${ }^{4}$ National Centers for Environmental Prediction/Environmental Modeling Center, 5830 University \\ Research Court, College Park, MD 20740, USA \\ ${ }^{5}$ Chemical Sciences Division, NOAA Earth System Research Laboratory, Boulder, CO 80305, USA \\ ${ }^{6}$ Cooperative Institute for Research in Environmental Sciences, University of Colorado, Boulder, \\ CO 809309, USA \\ * now at: University of Wisconsin-Madison College of Agricultural Life and Sciences, \\ 1450 Linden Drive, Madison, WI 53706, USA \\ *** now at Air Resources Laboratory, NOAA, 5830 University Research Court, \\ College Park, MD 20740, USA
}

Correspondence to: P. A. Cleary (clearypa@uwec.edu)

Received: 17 June 2014 - Published in Atmos. Chem. Phys. Discuss.: 10 September 2014

Revised: 27 March 2015 - Accepted: 1 April 2015 - Published: 6 May 2015

\begin{abstract}
Air quality forecast models typically predict large summertime ozone abundances over water relative to land in the Great Lakes region. While each state bordering Lake Michigan has dedicated monitoring systems, offshore measurements have been sparse, mainly executed through specific short-term campaigns. This study examines ozone abundances over Lake Michigan as measured on the Lake Express ferry, by shoreline differential optical absorption spectroscopy (DOAS) observations in southeastern Wisconsin and as predicted by the Community Multiscale Air Quality (CMAQ) model. From 2008 to 2009 measurements of $\mathrm{O}_{3}$, $\mathrm{SO}_{2}, \mathrm{NO}_{2}$ and formaldehyde were made in the summertime by DOAS at a shoreline site in Kenosha, WI. From 2008 to 2010 measurements of ambient ozone were conducted on the Lake Express, a high-speed ferry that travels between Milwaukee, WI, and Muskegon, MI, up to six times daily from spring to fall. Ferry ozone observations over Lake Michigan were an average of $3.8 \mathrm{ppb}$ higher than those measured at shoreline in Kenosha, with little dependence on position of
\end{abstract}

the ferry or temperature and with greatest differences during evening and night. Concurrent $1-48 \mathrm{~h}$ forecasts from the CMAQ model in the upper Midwestern region surrounding Lake Michigan were compared to ferry ozone measurements, shoreline DOAS measurements and Environmental Protection Agency (EPA) station measurements. The bias of the model $\mathrm{O}_{3}$ forecast was computed and evaluated with respect to ferry-based measurements. Trends in the bias with respect to location and time of day were explored showing nonuniformity in model bias over the lake. Model ozone bias was consistently high over the lake in comparison to landbased measurements, with highest biases for $25-48 \mathrm{~h}$ after initialization.

\section{Introduction}

Air quality near Lake Michigan has been under study for more than 30 years (Lyons and Cole, 1976; Keen and Lyons, 
1978; Dye et al., 1995). The shoreline air quality has gone from a highly impacted environment for surface ozone in the 1970 s-80s to persistent non-attainment status in the 2008 ground-level ozone standards for counties near to Lake Michigan in Wisconsin (Sheboygan and Kenosha), Illinois (Cook, Lake, Grundy, Kane, Kendall, McHenry, Will) and Indiana (Lake, Porter). The number of critical ozone events in the Chicago metro area region has been reduced in the past 20 years (EPA, 2014), but stricter measures for particulates have maintained a steady pattern of particulate matter exceedances for this region (Katzman et al., 2010; Stanier, 2012). Non-attainment of federal ozone standards is still of concern. Kenosha remains in marginal non-attainment of federal ozone standards (as of 2012), and Sheboygan County, north of Milwaukee, remains in non-attainment. The proposed rule as of 26 November 2014 is to reduce the $8 \mathrm{~h}$ primary standard to between 65 and $70 \mathrm{ppb}$ ozone, which has the possibility of maintaining the non-attainment status for these counties in the future (EPA, 2014). These Wisconsin counties in non-attainment are unique in that they are both suburban Lake Michigan shoreline counties as opposed to urban or rural counties. Studies have been addressing the role of lake breeze in air quality near the Great Lakes of North America (Levy et al., 2010; Sills et al., 2011; Makar et al., 2010), with a whole campaign, the Border Air Quality and Meteorological Study (BAQS-MET), dedicated to the evaluation of lake breezes. Complexities in the reduction of precursors and continued increases in ozone are of current concern in the Toronto area (Pugliese et al., 2014). Here, we evaluate the Lake Michigan ozone mixing ratios offshore with those onshore, including agreement with ozone forecast models over water and at the shoreline.

Ozone is generated in the troposphere by the reaction of precursors (nitrogen oxides $\left(\mathrm{NO}_{x}\right)$ and volatile organic compounds (VOCs)) in a photochemical cycle that is typically most active during high-pressure events in summer. The Milwaukee-Chicago-Gary urban corridor constitutes a large emissions source for ozone precursors and is home to significant populations impacted by poor air quality. The understanding of ozone production and distribution around Lake Michigan requires monitoring of land-based sites yearround, but no regular observations of offshore air quality exist. Some land-based monitors are situated farther from Lake Michigan than others, but no specific quantification of the difference between surface level offshore air quality and onshore air quality exists on a routine basis. Forecast models typically produce large ozone mixing ratio maxima over Lake Michigan (Lennartson and Schwartz, 1999, 2002). The nature of the distribution of ozone precursor emissions near to the Lake Michigan shoreline from an urban corridor is in stark contrast to the reduced anthropogenic and biogenic emissions over the lake. This, combined with the unique meteorological effects from this large body of water - like the lake breeze, which can trap, stratify and recirculate air off- shore - highlights the need for ozone measurements at a nearshore site and across the lake.

The study of high-ozone events in the region has centered around mesoscale meteorological effects that contribute to the formation of ozone and the movement of air masses over land (Lennartson and Schwartz, 2002; Lyons and Cole, 1976). Lyons and Cole (1976) outlined the influence of the land-breeze effect on shoreline air quality. Lennartson and Schwartz (2002) indicated a pattern of high-pressure anticyclonic events as coincident with higher ozone abundances at land-based sites. Recently, Levy et al. (2010) investigated the impact of local-scale flows in Great Lakes air quality in the region of Lake Erie. Levy et al. (2010) determined that local-scale emissions play a significant role in ozone production, and the meteorological constraints on air movement aid in isolating and stratifying air pockets from which ozone is generated on a next-day basis.

A few studies have investigated offshore air quality in regional-scale monitoring of ozone around Lake Michigan. The two most notable studies are the Lake Michigan Air Quality Study in 1991, which used aircraft for monitoring (Dye et al., 1995), and the LADCO Aircraft Project (LAP; Foley et al., 2011). Dye et al. (1995) determined that stratification over Lake Michigan lead to limited vertical and horizontal mixing beyond the lake area during the summer, allowing for the confinement of ozone precursors. The LAP was a $9 \mathrm{yr}$ aircraft-based study to evaluate air quality in the region, where flights were conducted on days of suspected high ozone in non-attainment of hourly federal standards (Foley et al., 2011). The work from LAP is consistent with the interpretation presented by Dye et al. (1995) in that inversions over the lake created stable layers of urban plumes, and that air sampled at greater distance from the ChicagoMilwaukee shoreline tended to be more processed. Foley, et al. (2011) determined in the late 1990s and early 2000s that in lower altitude air (<200 m a.g.l.) ozone formation switched between VOC-limited conditions in the morning to $\mathrm{NO}_{x^{-}}$ limited in the afternoon and that, above $200 \mathrm{~m}$ a.g.l., ozone formation was always $\mathrm{NO}_{x}$ limited. The observations from LAP showed a progression of the "photochemical clock" during northward aircraft transects over the lake where more aged plumes were found farther north of Chicago. Fast and Heilman $(2003,2005)$ developed a regional, coupled meteorological and chemical model to describe ozone formation on or near the Great Lakes. For offshore measurements they used ozone observations from the SS Badger, which operates between Luddington, Michigan, and Manitowoc, Wisconsin. Their comparison between the model and measurements was poorest for the eastern side of Lake Michigan in 1999 but was restricted to specific times of the day due to ferry movement (Fast and Heilman, 2003). Their model results from 1999 and 2001 showed distinct features in the ozone spatial distribution over Lake Michigan but did not reproduce eastern Wisconsin shoreline observations when ozone mixing ratios were high (> $60 \mathrm{ppb}$ ) (Fast and Heilman, 2005). 
The Lake Michigan land-lake breeze is a welldocumented phenomenon that influences local-scale airflow due to differential heating of air masses over land and water on a daily basis (Lyons and Cole, 1976; Foley et al., 2011; Hanna and Chang, 1995; Lennartson and Schwartz, 2002). Offshore flow (the land breeze) is dominant during the nighttime during summer when surface waters are higher in temperature than land surface temperatures. For counties along the western side of Lake Michigan, this westerly pattern follows the typical westerly synoptic flow for the region. Onshore flow (the lake breeze) is more common in the summer daytime when land temperatures exceed water surface temperatures. The lake breeze has been seen to coincide with higher ozone, and the transport of aerosol in Chicago (Harris and Kotamarthi, 2005; Lyons and Olsson, 1973) and largerscale high-pressure anticyclonic flows have been implicated in the higher Lake Michigan shoreline ozone observations (Lennartson and Schwartz, 1999), which enhance the flow of photochemically aged air from the Chicago urban plume northward along the Lake Michigan shoreline to southeastern Wisconsin.

In this study, the deployment of both a long-path differential optical absorption spectrometer (DOAS) at the shoreline and an ozone monitor on a ferry has several benefits: the long path length for the DOAS instrument creates an averaged signal that is unaffected by small spatial-scale pointsource emissions and allows for simultaneous observations of several compounds $\left(\mathrm{NO}_{2}, \mathrm{SO}_{2}, \mathrm{O}_{3}\right.$, formaldehyde). This combination of species provides relevant information about air masses, where $\mathrm{O}_{3}$ is the pollutant of interest to compare with offshore observations; $\mathrm{NO}_{2}$ is a proxy for $\mathrm{NO}_{x}$ and a precursor to $\mathrm{O}_{3}$ production; formaldehyde is a proxy for total VOCs, which are other necessary ozone precursors; and $\mathrm{SO}_{2}$ is used as a tracer for industrial emissions and electric power generation. The use of a DOAS instrument for monitoring atmospheric species at a shoreline has proven effective in other environments, such as the observatory on the west coast of Ireland (Carpenter et al., 1999; Seitz et al., 2010); Crete (Vrekoussis et al., 2004); Galapagos Islands (Martin et al., 2013); Okinawa Island (Takashima et al., 2011); Houston (Rivera et al., 2010); Helgoland (Martinez et al., 2000); and Appledore Island, NH (White et al., 2008), to name a few. In the study described here, the four constituents measured by DOAS are used to show the change in chemical composition of air masses from offshore and onshore and to evaluate the spatial distribution of the species at the Lake Michigan shoreline. The routine monitoring of ozone over Lake Michigan on the ferry platform allows for an evaluation of the spatial distribution of ozone over the lake, comparison of over-water ozone to shoreline ozone and comparison to modeled forecasts of surface-level ozone. This investigation is the first to present high-resolution, regular observations of ozone at the surface over Lake Michigan in comparison to air quality model output. Results have been analyzed to show the difference between shoreline and over-water ozone as a function

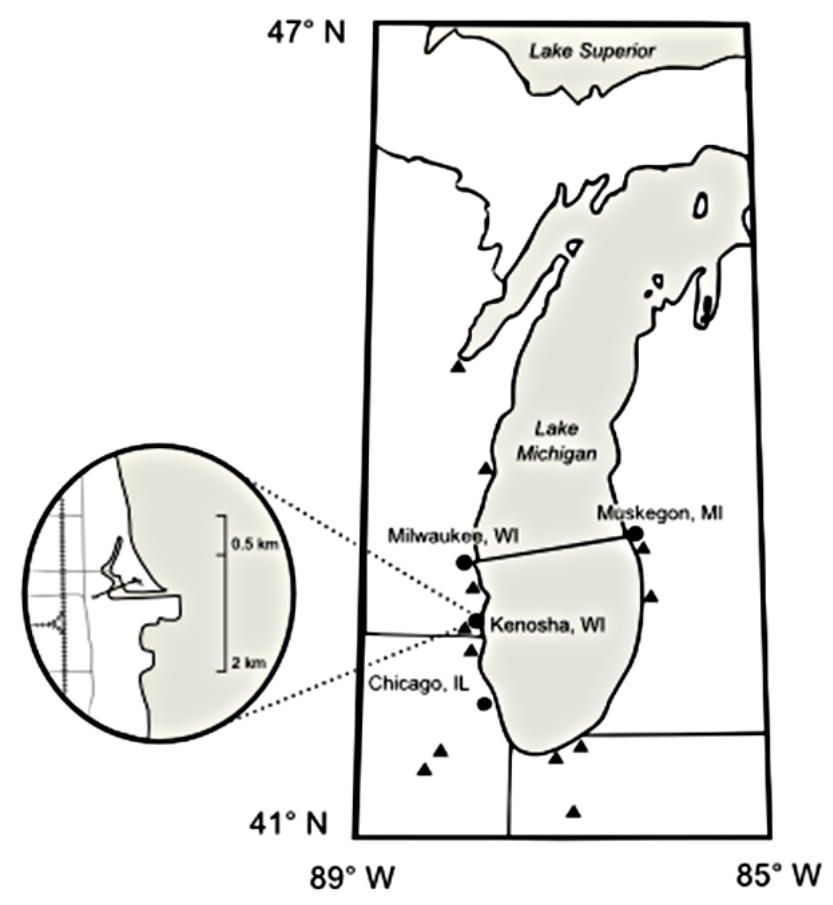

Figure 1. Map of experiment. Path of ferry from Milwaukee, Wisconsin, to Muskegon, Michigan, is shown with black line across the lake in the map. The DOAS instrument was placed at the Kenosha, Wisconsin harbor; the beam path is shown (inset) as the dark line across the harbor. Coal-fired power plants with power capacity greater than $400 \mathrm{MW}$ are shown as black triangles.

of time of year, time of day, location over the lake and meteorology.

\section{Methods}

Kenosha, Wisconsin, is located along the shoreline of Lake Michigan in the southeast corner of the state, bordering Illinois (Fig. 1). The commercial DOAS instrument was mounted to two municipal buildings at Kenosha harbor along Lake Michigan, spanning the harbor with a one-way singlebeam path length of $596 \mathrm{~m}$. The light source was mounted to the roof of the Kenosha municipal building at 625 52nd St, and the detector was housed at the Kenosha Water Utility Water Production Plant located at 100 51st Place on Simmons Island. The beam passed over land and water at 10 $14 \mathrm{~m}$ a.g.l. At this location, the shoreline of Lake Michigan is oriented north-south, with a small residential area directly south of the measurement site (see inset of Fig. 1). The measurement site is located in downtown Kenosha, a city of 100000 located 35 miles south of Milwaukee (metropolitan area population 2 million) and 50 miles north of Chicago (metropolitan area population 9.5 million). The DOAS unit was calibrated with known standards in September of 2008 ( $\pm 4 \%$ yearly drift). In-beam standards were used to test the calibration on 7 November 2008 and 8 August 2009. The 
instrument was operated from 19 September to 24 November 2008 and 28 April to 10 November 2009. Meteorological data (temperature, relative humidity, wind speed and direction) were obtained in 2009 by the addition of a meteorological station at the Kenosha harbor site of the DOAS detector. The meterological sensors were mounted to a pole extending $3 \mathrm{~m}$ above the rooftop where the DOAS detector was mounted. Data were collected as $1 \mathrm{~min}$ averages for each compound $\left(\mathrm{NO}_{2}, \mathrm{SO}_{2}, \mathrm{O}_{3}\right.$ and formaldehyde) sequentially, which resulted in single data points every $5 \mathrm{~min}(1 \%$ precision). Data were filtered for low light levels when the instrument required realignment. No post-processing filters (e.g., omitting data with low wind speeds) were placed on meteorological measurements.

The Lake Express ferry runs from May to October from Milwaukee, WI, to Muskegon, MI (Fig. 1), at 06:00 (eastbound), 09:15 (westbound), 12:30 (eastbound) and 15:45 (westbound) CDT and in late July/August also at 19:00 (eastbound) and 22:00 (westbound) CDT. Time zones for Wisconsin and Michigan differ, but all times given here are in Central Daylight Time. The ferry stays in port overnight in Milwaukee, and the average trip duration of the ferry for this study was $2.25 \mathrm{~h}$. The inlet for air monitoring was installed at the bow above the wheelhouse ( $3 \mathrm{~m}$ starboard of center and $10 \mathrm{~m}$ above water line), and approximately $15 \mathrm{~m}$ of 1/4 in. PTFE tubing was routed through the interior conduit into a utility closet where a commercial $\mathrm{CO}_{2}$ ( $\mathrm{Li}-\mathrm{Cor}$ ) and $\mathrm{O}_{3}$ (Thermo Scientific Model 49) monitor were housed. The sample line had a Teflon cartridge filter (changed approximately weekly) and tee fitting to the two instruments (each with independent pumps) with a sampling time lag of approximately $10 \mathrm{~s}$. The inlet was positioned to the stern so as to minimize water spray entering the sample lines, with intake tubing surrounded by a larger tubing as a rain/spray cover. The $\mathrm{O}_{3}$ instrument was installed on the ferry from 9 July to 21 September 2008, 12 May to 28 October 2009 and 23 June to 1 November 2010. GPS coordinates and gas measurements were recorded every $30 \mathrm{~s}$, resulting in a frequency/spatial resolution of $\sim 1 \mathrm{~min} \mathrm{~km}{ }^{-1}$, with an average speed of ferry at 30 knots. Zeros on the ozone monitor were conducted during power-down of the ferry (typically twice per day when ferry was docked in port). Ozone data were excluded from the data set when the ferry was in port because measurements were also influenced by engine emissions of NO. On occasion, due to inclement weather or mechanical problems, the ferry did not follow its posted schedule. The ozone instrument had a manufacturer-stated accuracy of \pm 2 ppbv. The ozone instrument was calibrated at NOAA before and after deployment each year by comparison of the instrument deployed on the ferry to a standard ozone monitor (Thermo Scientific Model 49i-PS) maintained in the laboratory for comparison purposes. Comparisons were always within $2 \%$. a)

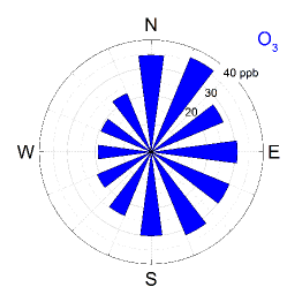

c)

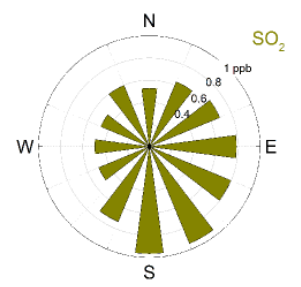

b)

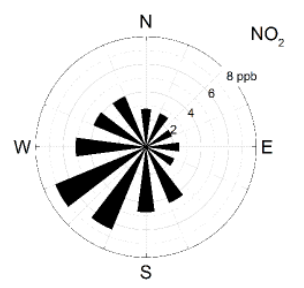

d)

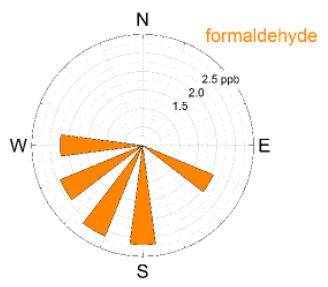

Figure 2. Wind rose depictions of median mixing ratio of (a) $\mathrm{O}_{3}$, (b) $\mathrm{NO}_{2}$, (c) $\mathrm{SO}_{2}$ and (d) formaldehyde with respect to wind direction as measured by DOAS at Kenosha harbor from April to November of 2009. Medians are not reported for wind directions where few measurements ( $n<75$ for 30 min averaged data points) were above the detection limit (d.1. $=1.5 \mathrm{ppb}$ for formaldehyde).

\section{Results}

\subsection{Shoreline DOAS observations as a function of wind direction}

Observations from the the Kenosha harbor DOAS instrument were evaluated with respect to offshore versus onshore air mass origin by sorting the data with respect to observed wind direction in 2009. For 2009, all 30 min averaged data were binned to median mixing ratio per $30^{\circ}$ increment of wind direction. Figure 2 shows the distribution of the median mixing ratios of gases $\mathrm{O}_{3}, \mathrm{NO}_{2}, \mathrm{SO}_{2}$ and formaldehyde with respect to wind direction. The highest median ozone and $\mathrm{SO}_{2}$ mixing ratios observed at the Kenosha harbor location arise from air masses flowing from the lake $\left(0-180^{\circ}\right.$ are from offshore), whereas the highest $\mathrm{NO}_{2}$ and formaldehyde observations arise from air masses originating on land. So few formaldehyde measurements in the onshore flow were above the detection limit that average data from those wind directions were omitted from Fig. 2d. The observation of $\mathrm{NO}_{2}$ from land-based air masses is consistent with localized fossil-fuel combustion sources of short-lived $\mathrm{NO}_{x}$ $\left(=\mathrm{NO}+\mathrm{NO}_{2}\right)$ coming from land-based mobile and point sources as $\mathrm{NO}_{x}$ oxidizes rapidly to other nitrogen species during the daytime. Formaldehyde can serve as a proxy for VOCs, with anthropogenic and biogenic emissions arising from sources on land, and can also be produced in situ as an oxidation product of VOCs. Formaldehyde can be lost to reaction with $\mathrm{OH}$ and photolysis during the day. The longerlived atmospheric species of $\mathrm{O}_{3}$ and $\mathrm{SO}_{2}$ were observed in higher abundance from offshore. The $\mathrm{O}_{3}$ and $\mathrm{SO}_{2}$ mixing ra- 


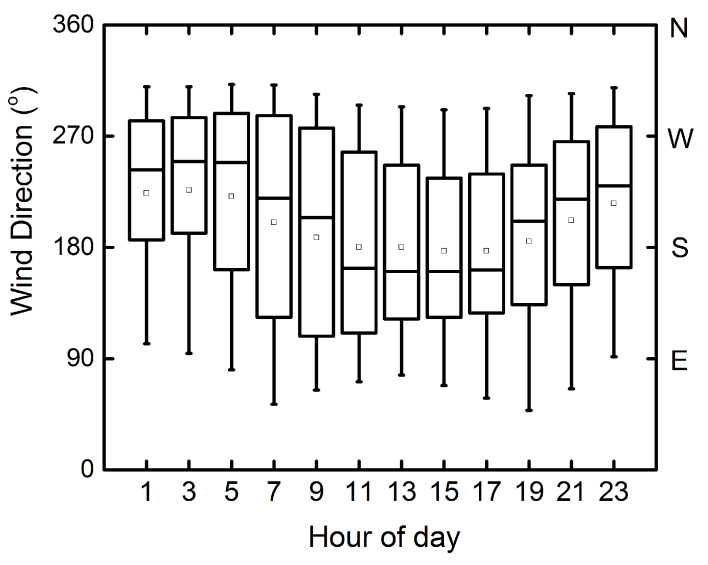

Figure 3. Wind direction as a function of time of day as measured at Kenosha harbor from April to November of 2009. Box plots show mean ( $\square$ ), median (centerline), 25-75\% (box) and 10-90\% (whiskers).

tios were otherwise not correlated on individual days, which is typical as the chemistry and emissions driving the evolution of each were quite different. $\mathrm{O}_{3}$ is produced by catalytic photochemical cycles which require the presence of $\mathrm{NO}_{x}$ and VOCs and can be titrated by fresh emissions of NO. Sulfur dioxide is most commonly emitted by fossil-fuel combustion at coal-fired power plants, many of which lie at the Lake Michigan shoreline in the Gary-Chicago-Milwaukee urban corridor from Indiana to Wisconsin. The diurnal wind patterns (Fig. 3) at the Kenosha harbor site also contribute to the apparent higher mixing ratios of ozone and $\mathrm{SO}_{2}$ over the lake because the lake-breeze wind pattern drives winds from land offshore at night (when $\mathrm{NO}_{2}$ and formaldehyde losses by photolysis and reaction with $\mathrm{OH}$ were minimized) and from the lake onshore during the day (when ozone mixing ratios were at a maximum). This maximum for $\mathrm{NO}_{2}$ arriving from offshore air masses we interpret as an artifact of $\mathrm{NO}_{2}$ minima midday coinciding with onshore air masses, even though sources (both mobile and stationary) of $\mathrm{NO}_{2}$ are predominantly located on land. The nighttime $\mathrm{NO}_{2}$ maxima is likely from lower nighttime losses of $\mathrm{NO}_{2}$ (not to be mistaken for nighttime $\mathrm{NO}_{x}$ losses, which can still be significant (Brown et al., 2004)) instead of indicating some high $\mathrm{NO}_{x}$ emissions source from offshore at night.

These DOAS observations align with past studies of Lake Michigan air quality in that they implicate higher $\mathrm{O}_{3}$ mixing ratios over Lake Michigan (Dye et al., 1995; Foley et al., 2011; Lennartson and Schwartz, 1999, 2002). The higher $\mathrm{SO}_{2}$ mixing ratios may show the influence of power plant emissions mixing over longer distances and timescales over the lake. The nearest power plants to the DOAS site are located to the southwest (Pleant Prairie), north (Oak Creek) and south (Waukegan), and yet $\mathrm{SO}_{2}$ observations are highest from the southeastern quadrant, including from the south and east. The lifetime of $\mathrm{SO}_{2}$ is long enough (ca. 1 week) that sources from other power plants neighboring Lake Michigan (see Fig. 1) may contribute to these observations. Foley et al (2011) described sampling high- $\mathrm{NO}_{x}$ plumes over Lake Michigan that appeared to remain aloft. They suggested that these plumes originated from power plants in the region, which would also be a source of $\mathrm{SO}_{2}$. The shoreline observations presented here do not constrain the extent to which ozone was higher over the lake, nor the distribution of ozone across the lake, but only show that air with enhanced ozone was observed during afternoon hours when the air moved inland during the lake breeze. At the intersection between the offshore environment and the onshore environment, titration of $\mathrm{O}_{3}$ occurs via emissions from local $\mathrm{NO}_{x}$ sources, and therefore the additional offshore processing cannot be distinguished from chemistry at the shoreline with this DOAS measurement alone.

\subsection{Comparison between shoreline DOAS and ferry observations}

Kenosha shoreline DOAS observations of $\mathrm{O}_{3}$ were compared with the Lake Express ferry $\mathrm{O}_{3}$ observations in order to understand the regional distribution of ozone. The two measurements were compared by averaging the ferry measurements to $30 \mathrm{~min}$ intervals at the timescale of the Kenosha harbor DOAS measurements. The two instruments were never intercompared at the same location, so we estimate an uncertainty in their intercomparison at 5\% (which is higher than the stated drift of either instrument as evaluated independently). The differences in $30 \mathrm{~min}$ averaged data from 2009, as measured as $\mathrm{O}_{3}$ (Lake Express Ferry) $-\mathrm{O}_{3}$ (Kenosha harbor), fluctuated from as high as $45 \mathrm{ppb}$ to $-37 \mathrm{ppb}$, with a median difference of $2.8 \mathrm{ppb}$, mean of $3.8 \mathrm{ppb}$ and standard deviation of $9.1 \mathrm{ppb}$. The daily maximum data ( $30 \mathrm{~min}$ average) had a range of $39 \mathrm{ppb}$ to $-9 \mathrm{ppb}$, a median of $4.2 \mathrm{ppb}$, mean of $5.0 \mathrm{ppb}$ and a standard deviation $7.6 \mathrm{ppb}$. The time of peak ozone for ferry measurements was approximately 14:00-17:00 CDT for the whole campaign and for the DOAS measurements was from 14:00 to 16:00 CDT, which are not considerably different. Day-to-day variations in the time of peak ozone offshore versus onshore can occur from changes in wind direction and local $\mathrm{NO}_{x}$ sources at the shoreline Kenosha site; they therefore cannot be used to indicate differences in chemical processing over the day. There is a statistically significant difference in the $\mathrm{O}_{3}$ distribution over land vs. lake from summer (June, July, August) to fall (September, October), with median difference of $3.3 \mathrm{ppb}$ for summer and $1.6 \mathrm{ppb}$ for fall (KruskalWallis $p=0.05$ ).

In order to demonstrate the agreement between ozone measurements of both platforms, Fig. 4 shows the wind direction, $\mathrm{O}_{3}$ measurements, the difference in ozone measurements, temperature, $\mathrm{NO}_{2}, \mathrm{SO}_{2}$ and formaldehyde for 12 to 18 August 2009. This week was chosen because of the range of ozone maxima depicted (with daily maxima ranging from 40 to $70 \mathrm{ppb}$ ) and the example of a wind shift event that cor- 


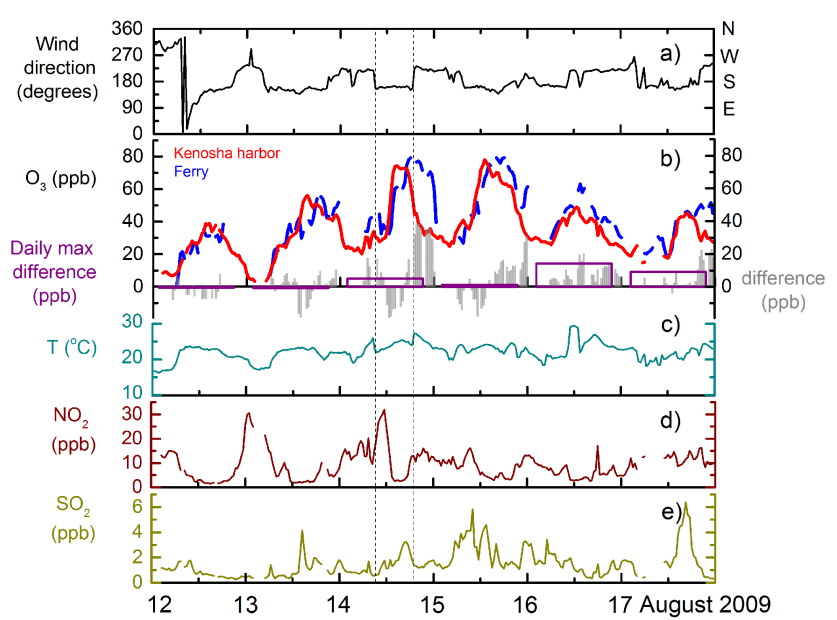

Figure 4. Example period of observations from 12 to 18 August 2009. (a) Wind direction at the Kenosha harbor site; (b) concurrent $\mathrm{O}_{3}$ observations from Kenosha harbor and Lake Express in transit, their $30 \mathrm{~min}$ average $\mathrm{O}_{3}$ (ferry) $-\mathrm{O}_{3}$ (Kenosha harbor) difference and daily max difference (c) temperature at Kenosha harbor in Celsius (d) $\mathrm{NO}_{2}$ observations from Kenosha harbor and (e) $\mathrm{SO}_{2}$ observations from Kenosha harbor.

related to temperature and atmospheric composition changes at the shoreline on 14 August. In the example of $12 \mathrm{Au}-$ gust 2009, the ozone mixing ratios for both instruments appear quite similar. Note that the discontinuities in ferry data represent times when the ferry was in port, and each of the segments between the data gaps represents an entire transect of Lake Michigan. In some cases, such as 12 August, there was very little variation in the difference between ferry and shoreline $\mathrm{O}_{3}$ with respect to the location of the ferry. For 13 August, the maximum ozone as measured at the shoreline $(\sim 50 \mathrm{ppb})$ was observed by the ferry upon return to the western side of Lake Michigan and again when it left, with roughly a $15 \mathrm{ppb}$ difference between the eastern and western sides of Lake Michigan in the afternoon hours. $\mathrm{NO}_{2}$ measurements in Fig. 4d peaked at night as high as $30 \mathrm{ppb}$ and were at a minimum during the day, particularly after noon. The mixing ratios of $\mathrm{NO}_{2}$ for this period do not correlate with $\mathrm{SO}_{2}$ mixing ratios and so can be considered to be from different emissions sources, such as urban non-point-source $\mathrm{NO}_{x}$ and power plant or industrial sources of $\mathrm{SO}_{2}$.

Evidence of lake-breeze shifts in the data was most clearly shown on 14 August (indicated by dotted lines in Fig. 4). The wind direction shifted abruptly from southwest (offshore flow) until about 10:00 CDT, when it shifted to southeast (onshore flow). The temperature change between these two air masses is evident in Fig. 4c, where the ambient temperature dropped $3{ }^{\circ} \mathrm{C}$ as the wind direction shifted. The $\mathrm{NO}_{2}$ mixing ratio increased to $30 \mathrm{ppb}$ after the wind shift, which may be evidence of recent land-based $\mathrm{NO}_{2}$ emissions from the northern Chicago area flowing offshore during rush hour and then returning onto land after the wind shift. Following the

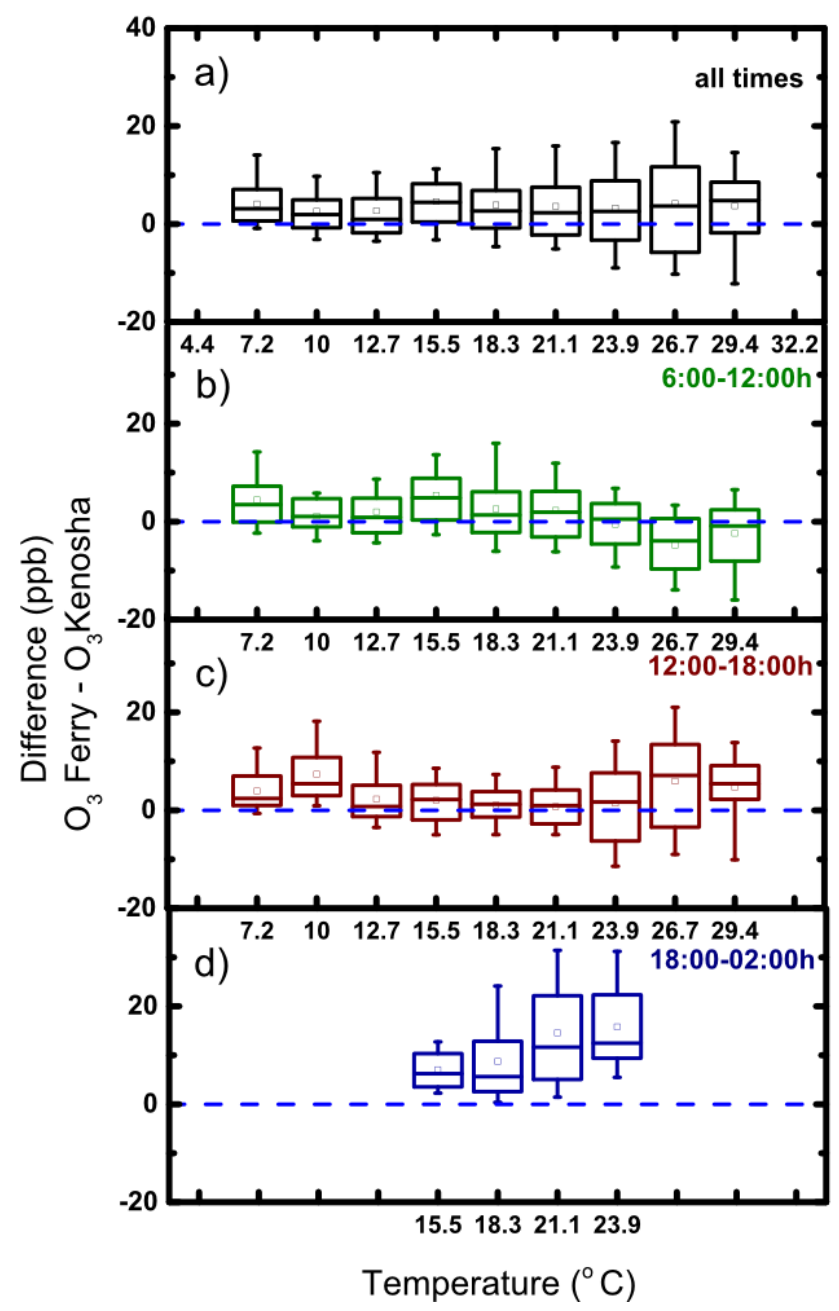

Figure 5. Difference in $\mathrm{O}_{3}$ observations between platforms with respect to temperature $\left({ }^{\circ} \mathrm{C}\right)$ measured at the shoreline for (a) all times, (b) morning (06:00-12:00 CDT), (c) early afternoon (12:0016:00 CDT) and (d) late afternoon/evening (16:00-02:00h). Box plots show mean ( $\square$ ), median (centerline), 25-75\% (box) and 10$90 \%$ (whiskers). Each box represents a minimum of 15 points.

rapid $\mathrm{NO}_{2}$ decrease, $\mathrm{O}_{3}$ increased as measured at the shoreline and also as measured on the ferry. By 18:00 CDT, the wind shifted back to arriving at the Kenosha harbor site from the southwest, and the shoreline ozone decreased precipitously, but the ferry observations of ozone remained high. The shoreline $\mathrm{NO}_{2}$ mixing ratios also rebounded to $12 \mathrm{ppb}$. In this case, the maximum $\mathrm{SO}_{2}$ observations arrived at the Kenosha harbor site from offshore later in the afternoon before the wind shifted. The HYSPLIT back trajectory model was calculated for the morning of 14 August for synoptic winds at $250 \mathrm{~m}$ a.g.l. and indicated an air mass arriving from the northeastern suburbs of Chicago, Illinois, which would intercept the rush-hour traffic emissions. Thus, the low $\mathrm{O}_{3}$ midmorning was a result of near-source and early-day $\mathrm{NO}_{x}$ titration. On 13, 14 and 15 August, $\mathrm{NO}_{2}$ increased following 


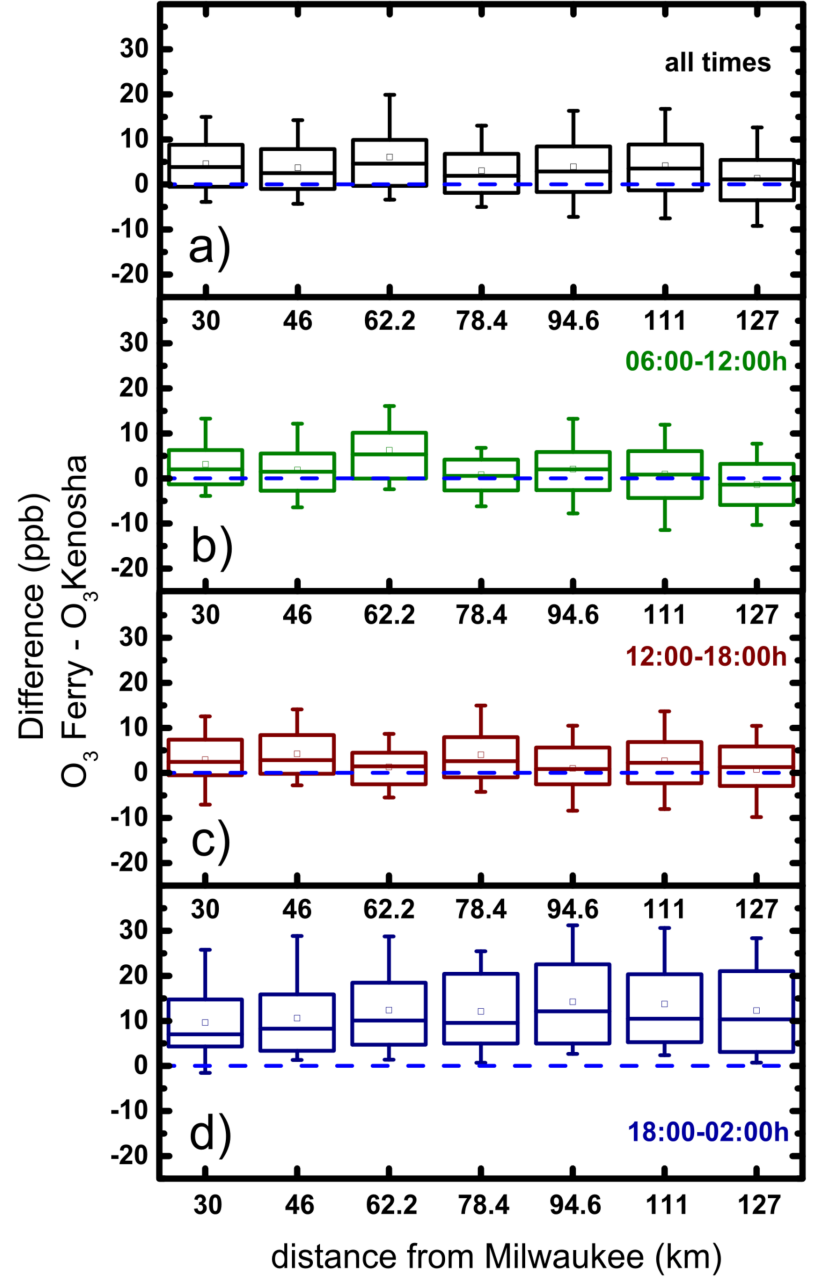

Figure 6. Difference in $\mathrm{O}_{3}$ observations between platforms with respect to position of the ferry as indicated by kilometers from Milwaukee along ferry path at (a) all times, (b) morning (06:0012:00 CDT), (c) early afternoon (12:00-16:00 CDT) and (d) late afternoon/evening (16:00-02:00 h). Box plots show mean ( $\square$ ), median (centerline), 25-75\% (box) and 10-90\% (whiskers). Each box plot represents a minimum of 12 points.

the wind shift between southwesterly and southeasterly wind flows. Hysplit back trajectories were generated for each of these days, which showed air masses from Chicago transported northward along the shoreline at the same time of day. Emissions were likely brought back on land from lake breezes, which could not be resolved from back trajectories.

Differences between ferry $\mathrm{O}_{3}$ and shoreline DOAS $\mathrm{O}_{3}$ mixing ratios were evaluated with respect to temperature (Fig. 5), location of the ferry (Fig. 6) and wind direction (Fig. 7). Each figure shows the data for all times of the day, and for distinct time windows (06:00-12:00 CDT, 12:00-18:00 CDT, 18:00-02:00 CDT) in box plots which represent mean (line), median ( $\square$ ), 25-75\% (box) and 10$90 \%$ (whiskers) for the $30 \mathrm{~min}$ average difference between

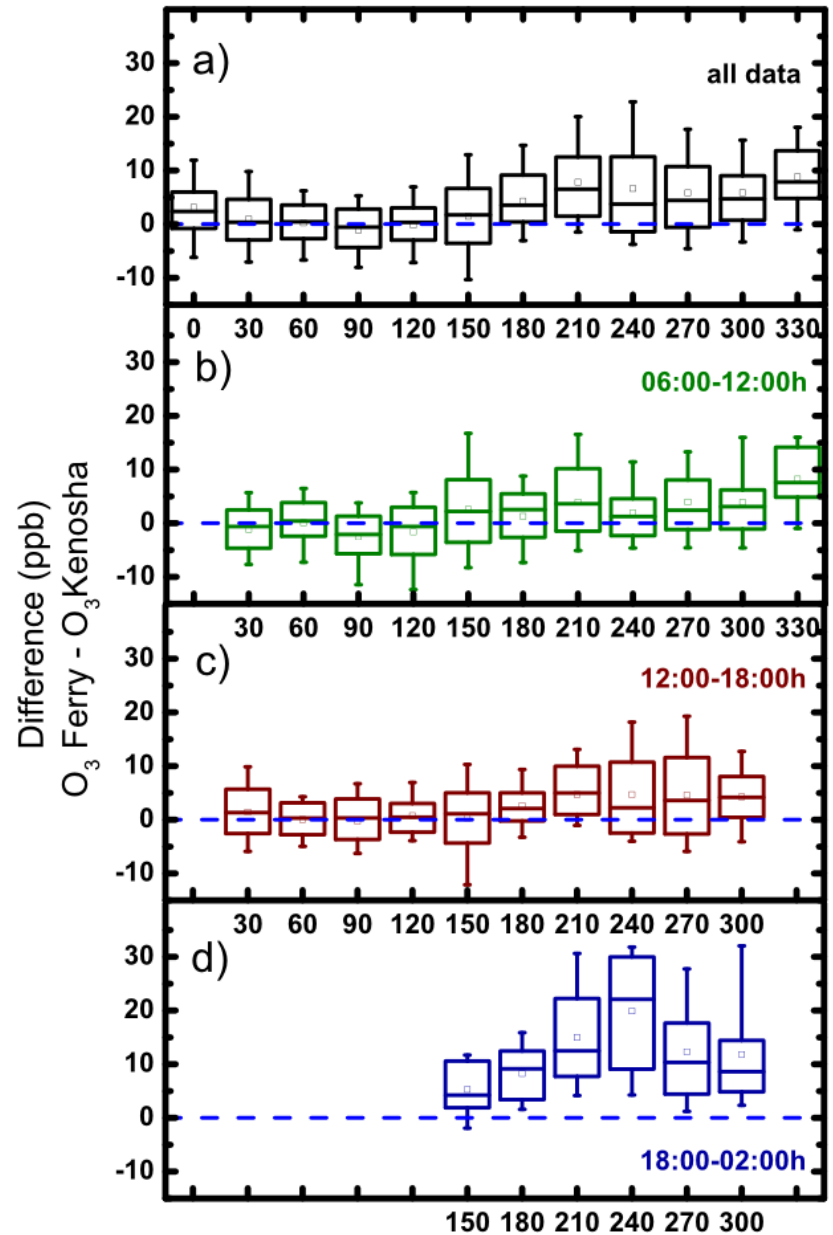

Wind Direction $\left({ }^{\circ}\right)$

Figure 7. Difference in $\mathrm{O}_{3}$ observations between platforms with respect to wind direction measured at Kenosha harbor for (a) all times, (b) morning (06:00-12:00 CDT), (c) early afternoon (12:0016:00 CDT) and (d) late afternoon/evening (16:00-02:00 h). Box plots show mean ( $\square$ ), median (centerline), 25-75\% (box) and 10$90 \%$ (whiskers). Each box represents a minimum of 15 points.

$\mathrm{O}_{3}$ (Lake Express) and $\mathrm{O}_{3}$ (Kenosha harbor). Differences between ozone observations from the ferry and shoreline with respect to temperature were investigated (Fig. 5). There was no observed trend in difference in ozone versus temperature for all data (Fig. 5a). A minor trend in median difference in ozone versus temperature is observed for morning times (06:0012:00 CDT, Fig. 5b) where the difference changed from a positive difference to a more negative difference with increasing temperature above $15.5^{\circ} \mathrm{C}$, and an opposite trend toward higher ozone over the lake in the afternoon (12:0018:00 CDT) and for temperatures above $26^{\circ} \mathrm{C}$. Ozone differences after 18:00 CDT show consistently higher ozone mixing ratios over the lake for all temperatures (Fig. 5d), with a trend for larger differences above $21.1^{\circ} \mathrm{C}$. 
For each of the graphs in Fig. 5, we conducted a KruskalWallis $(\mathrm{K}-\mathrm{W})$ non-parametric statistical test of whether the distributions depicted in each box plot in the figure could be considered different from each other. For Fig. 5a, the K$\mathrm{W}$ test indicated that no difference in the distributions (as depicted by box plots across different temperatures) could be determined within $95 \%$ confidence. For Figs. 5b and c the distributions (as depicted as box plots across different temperatures) could be considered different with $75 \%$ confidence. In Fig. 5d, the K-W test indicated that the distributions were significantly different with $95 \%$ confidence. The K-W test does not indicate a trend, just whether one or more distributions with the comparison are different from each other. K$\mathrm{W}$ tests applied across different times of day for a given temperature range (a vertical comparison in the stacked plots) consistently showed a significant difference in distributions (with $95 \%$ confidence).

While the chemistry can drive more ozone production at higher temperatures, the fact that the largest differences were observed in the evening and at night might arise from the isolation of air masses at this time from the lake-land breeze effects. If the air masses observed at the shoreline arrived from inland in the late evening, they could have been chemically different from those found far offshore. The only time when shoreline DOAS ozone observations tended to be higher than those from the ferry was at 06:00-12:00 CDT for temperatures above $26.7^{\circ} \mathrm{C}$. This may be due to days when temperatures were high in the morning, thus stagnating the air and limiting the influence of lake-land breeze on horizontal movement of air masses. Differences in offshore and shoreline observations of ozone with respect to temperature were largest later in the day and at higher temperatures when ozone was typically at a maximum. The range in temperatures observed from different wind directions was higher in wind arriving from land $\left(180-360^{\circ}\right)$ in comparison to over water $\left(0-180^{\circ}\right)$, such that the median temperature of all masses arriving at the site from the east was $12.8^{\circ} \mathrm{C}$ and from the west was $9.3^{\circ} \mathrm{C}$. The highest differences depicted in Fig. 7 show the highest ozone differences between shoreline and offshore measurements from a wind direction where temperatures are not as extreme.

Investigations into the ozone differences between shoreline and ferry observations with respect to ferry location were conducted as a test of the east-west gradient over Lake Michigan. Figure 6 depicts the difference of $\mathrm{O}_{3}$ (Lake Express) $-\mathrm{O}_{3}$ (Kenosha harbor) with respect to ferry distance from Milwaukee. For all data the mean and median difference was positive (i.e., greater over water as measured from the ferry). The median differences were not significantly positive or negative for the morning, were slightly positive for the early afternoon time window and were consistently positive for the late afternoon/evening. In the case of the late-evening time window, the mean, median and extremes $(25-75 \%)$ of the data all lie above 0 , which is a strong suggestion that at these times the ozone mixing ratios over the lake are consistently higher than at the shoreline. However, there does not appear to be a significant variation with respect to longitude, meaning that, evaluated as a whole, the land-lake differences in ozone did not depend on the ferry's distance from the shoreline. All K-W tests for each plot in Fig. 6 show no difference (95\% confidence) in distributions across different locations, corroborating this assertion. The only $\mathrm{K}-\mathrm{W}$ tests that showed a difference in distributions in Fig. 6 were comparisons with respect to time of day, which is similar to the time of day tests for Fig. 5. This demonstrates a widely uniform distribution of ozone over the lake.

In order to distinguish between meteorological effects at the shoreline, the differences in ozone observations from the ferry and shoreline DOAS ozone mixing ratios with respect to wind direction at Kenosha harbor were evaluated. All data (Fig. 7a) show a trend in which the differences between offshore and onshore observations of ozone are positive (i.e., greater ozone over water as measured from the ferry) when wind arrives at the Kenosha harbor site from 180 to $360^{\circ}$ (inland) where the median and mean lie above 0 . However, a K-W test for all data does not show a significant difference in the distributions with $95 \%$ confidence. When broken up into time windows of morning, afternoon and evening/night, the largest differences were observed after 18:00 CDT if winds were arriving from 180 to $360^{\circ}$. The $\mathrm{K}-\mathrm{W}$ tests only showed a difference in distributions across wind direction for Fig. 7d with $75 \%$ confidence. This picture is consistent with land breezes developing in the evening and producing surface winds which draw from land and move over the lake. The sampled air masses at the shoreline, thus, were of different origin (or sampled air masses over the lake were isolated from land-based air masses). The number of data points $(n<15)$ acquired when the wind blew from 30 to $160^{\circ}$ from 18:00 to 02:00 CDT was insufficient for analysis. For the morning and early afternoon times, the trend with respect to wind direction was not large.

The two key differences between ferry and shoreline ozone observations in these comparisons were those after 18:00 CDT and into the night, as shown in Figs. 5, 6 and 7 (all of which were significantly different from other times of day based on K-W tests with $95 \%$ confidence) and the trend with the wind direction for all times of the day with the mean difference for wind directions from 0 to $180^{\circ}$ at $0.2 \mathrm{ppb}$ and for wind directions from 180 to $360^{\circ}$ at $6.3 \mathrm{ppb}$. This trend in the dependence of the observed ozone difference with respect to wind direction is magnified after noon. One possible key driver of differences between observed offshore and shoreline ozone could be the differences in $\mathrm{NO}_{x}$ emissions from each wind direction. The trends with respect to temperature are small in comparison to the trends with respect to wind direction and may be a subtle indicator of the strength of lake-breeze effects. Trends with temperature may demonstrate some differences in photochemistry, where some aspects of photochemical ozone production are enhanced with temperature (water vapor content, VOC emissions). Trends 
with location could be influenced by the distance from emissions sources at the western Lake Michigan shoreline, or lower losses of $\mathrm{O}_{3}$ to water surfaces compared to terrestrial surfaces (Levy et al., 2010). One complicating factor is that the ferry intercepted air near the surface, whereas urban plumes might reside aloft over an inversion above the lake (Foley et al., 2011; Dye et al., 1995). However, the subtleties of these effects appear to be outweighed by the magnitude of air mass isolation effects due to local meteorology, as indicated by the large ozone mixing ratio trends with wind and time of day. More complex yet similar observations near Lake Erie were made in summer 2007 during BAQS-Met by Levy et al. (2010), where oscillations in inland ozone were observed at times associated with lake-breeze front movement. The extent to which inversion occurs over the lake at night and ozone precursors and ozone mixing ratios remain high aloft, as suggested by Dye et al. (1995) and Foley et al. (2011), cannot be evaluated by our measurements at the surface.

\subsection{Comparison of ferry ozone with CMAQ experimental model forecasts}

The National Air Quality Forecast Model (NAQFM) was developed with the collaboration of the National Oceanic and Atmospheric Administration (NOAA) and the Environmental Protection Agency (EPA) (Eder, 2009). The NAQFM is made up of two components: the National Center for Environmental Prediction's (NCEP) North American Mesoscale (NAM) meteorological model and the EPA's Community Multiscale Air Quality (CMAQ) modeling system (Janjic, 2003; Eder 2009; Byun and Schere, 2006). The NAM is used to input meteorological conditions into the CMAQ to generate $48 \mathrm{~h}$ forecasts. Initialization steps to the forecasts are conducted every $12 \mathrm{~h}$ at 06:00 and 12:00 UTC (Eder 2009; Chai 2010). The NAQFM provides real-time predictions for ground-level ozone mixing ratios over the contiguous US (Eder, 2009) with a $12 \mathrm{~km}$ grid size. The NAQFM CMAQ runs in three modes: operational, experimental and developmental, with the operational product displayed publicly on the NAQFM website (Fig. 8, for illustration purposes only, shows an example of the operational product for 24 June 2009, along with the Lake Express ferry measurements on that day). Here we compare observations with the developmental model product which used the Carbon Bond Mechanism 5 (CB05) gas-phase chemical mechanism. The emissions inventory used in model forecasts is adopted from the EPA's 2005 National Emissions Inventory (NEI) (Pan, 2014).

Hourly output from the developmental CMAQ forecasts were saved for the monitoring season of 2009 from 18 June to 15 September 2009. The CMAQ output ozone mixing ratios were reported to $1 \mathrm{ppb}$ precision. Figure 9 depicts $\mathrm{O}_{3}$ forecast levels consistently higher than ferry measurements with 57 days of overlapping data. These forecasts produce a distinct ozone maximum over the water surfaces of the Great Lakes a)
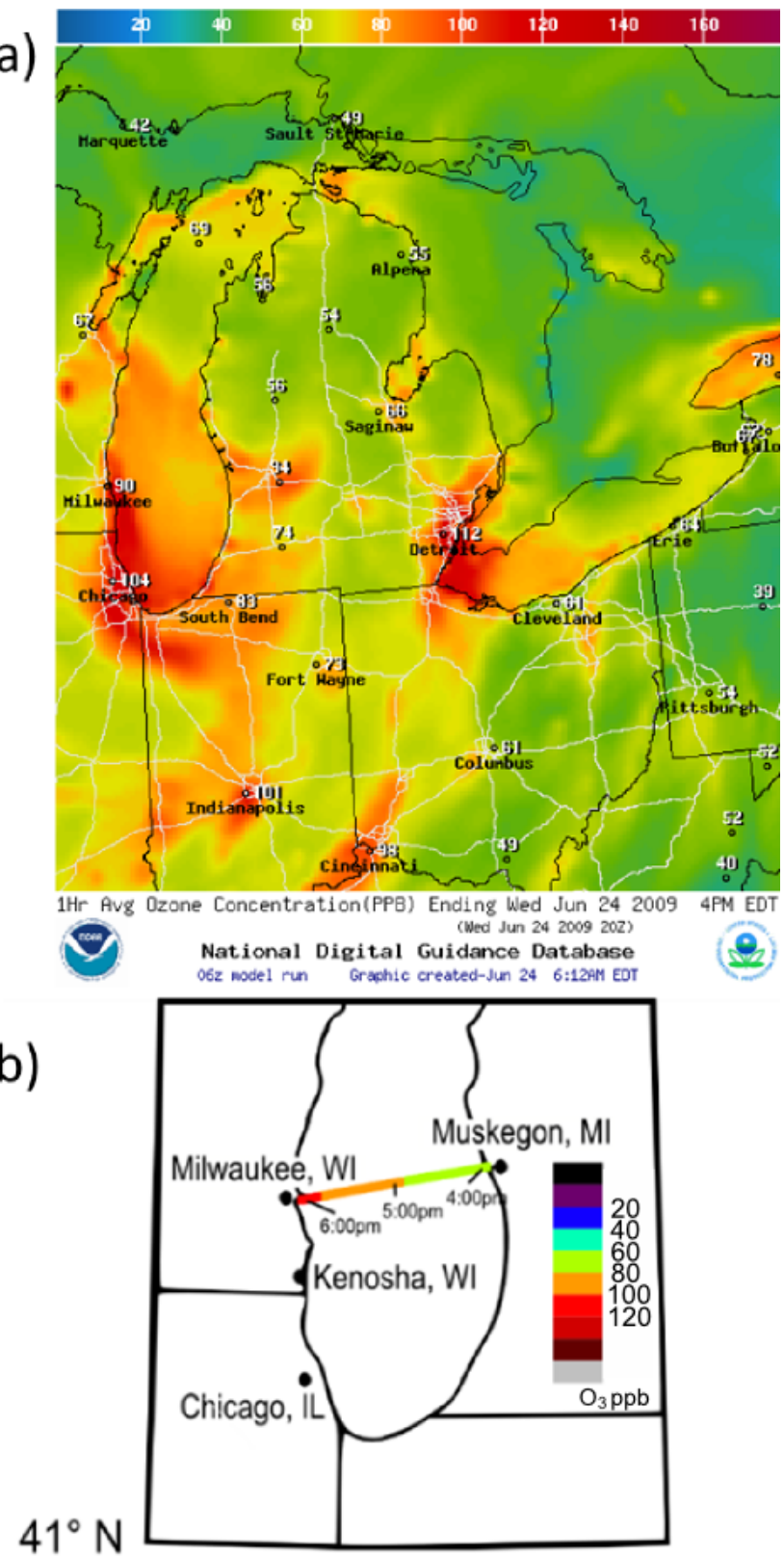

$89^{\circ} \mathrm{W}$

$85^{\circ} \mathrm{W}$

Figure 8. (a) Sample image of National Air Quality Forecast Model (NAQFM) during the campaign period, (b) $\mathrm{O}_{3}$ measurements for one ferry trip on 24 June 2009 where the ferry was in transit from $15: 50$ to $18: 15$ CDT.

and, in particular, southern Lake Michigan (e.g., Fig. 8). Statistical comparisons with the Lake Express observations use model grid and time values determined from ship tracks through the model domain and with no spatial or temporal interpolation. Figure 10 depicts the sample numbers within distinct model grid cells for the 3-month time period according to model longitude and central daylight time for the ferry transects. The extreme western and eastern points are within 


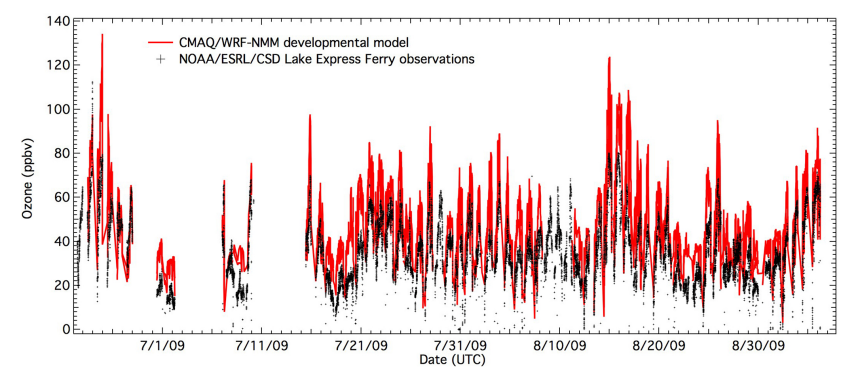

Figure 9. Graph of all CMAQ model forecast ozone mixing ratios in red with Lake Express Ferry observations in black from 2009.

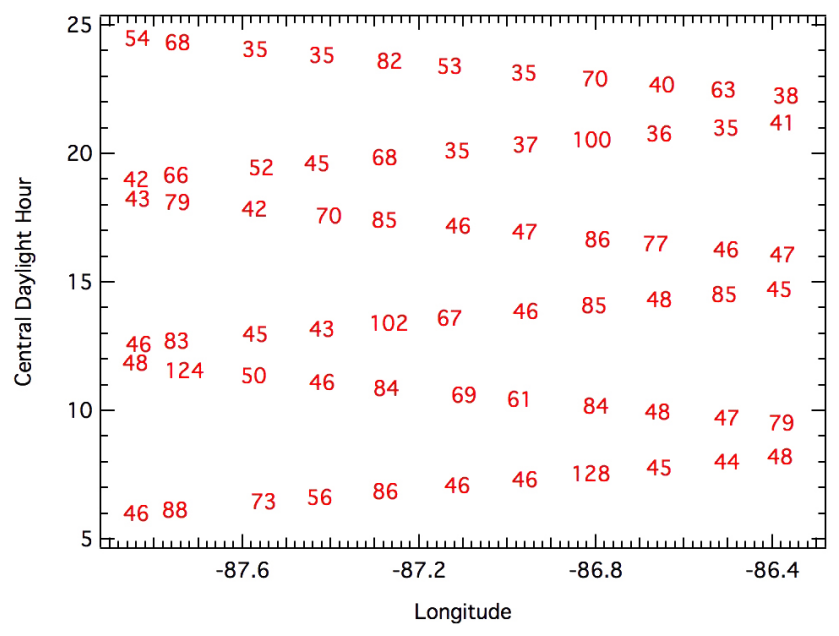

Figure 10. Statistical data for CMAQ model and ferry measurement comparison. Each model grid value and observation averages were binned according to model west-east grid number and time (CDT) of the ferry transect. The 1 min $\mathrm{O}_{3}$ observations were averaged over model grid and hourly output. The numbers here are the number of hourly comparisons between model grid values and hourly averaged $\mathrm{O}_{3}$ observations via ferry.

ports, and the Milwaukee model grid is over land. The model comparison may not be reliable for the shoreline grids due to local sources and contamination by ferry exhaust. Figure 11 shows the median ozone values for the forecast $1-24 \mathrm{~h}$ after model initialization (11a), 25-48 h after initialization (11b) and Lake Express monitor (11c). Figure 11 depicts distinct higher model median $\mathrm{O}_{3}$ forecasts in comparison to observations. The maxima in the model forecast $\mathrm{O}_{3}$ are midlake from 15:00 to 18:00 CDT. The forecast $\mathrm{O}_{3}$ mixing ratios are highest $25-48 \mathrm{~h}$ after initialization, especially between 14:00 and 21:00 CDT. The location of the daily maximum ozone from the ferry is similar to the distribution given by the CMAQ for 1-24 h after initialization (Figs. 11a, c). The CMAQ predicts the highest median daily maximum $\mathrm{O}_{3}$ just offshore on the eastern side of Lake Michigan for 1-24 h after initialization (Fig. 11a) and a larger area for $25-48 \mathrm{~h}$ after initialization (Fig. 11b). The correlation coefficients between model and measurement are high $(R=0.85$ to 0.95$)$ from a)

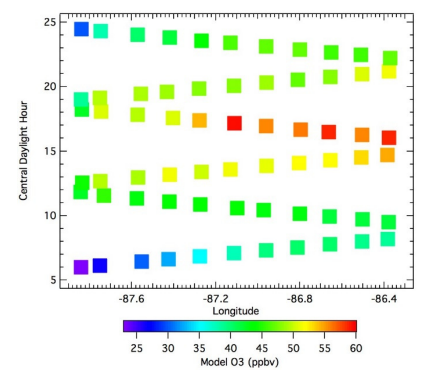

b)

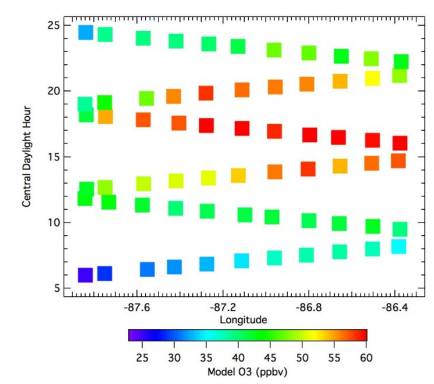

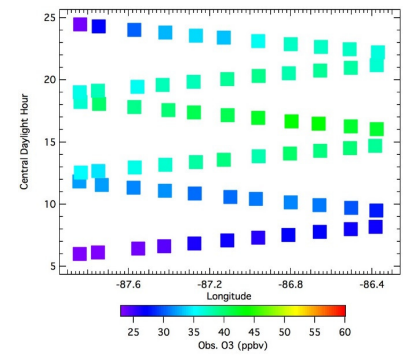

Figure 11. Median $\mathrm{O}_{3}$ from (a) 1 to $24 \mathrm{~h}$ CMAQ forecasts, (b) 25 to $48 \mathrm{CMAQ}$ forecasts and (c) ferry observations.

14:00 to 17:00 CDT for the $1-24 \mathrm{~h}$ forecast (Fig. 12a). The correlations were reduced for the $25-48 \mathrm{~h}$ forecast (Fig. $12 \mathrm{~b}$ ).

The comparison between the ozone forecast and the ferry observations were computed as bias:

bias $=p_{\mathrm{i}}-o_{\mathrm{i}}$,

where $p_{\mathrm{i}}$ is the model-predicted $\mathrm{O}_{3}$ mixing ratio and $o_{\mathrm{i}}$ is the observed $\mathrm{O}_{3}$ mixing ratio on the ferry. Bias was determined for each sample location and time referenced in Fig. 10. Model bias is shown in Fig. 13. The forecast from 1 to $24 \mathrm{~h}$ after initialization in Fig. 13a shows an 11-16 ppb median $\mathrm{O}_{3}$ bias for offshore locations, which is highest between 12:00 and 17:00 CDT. The 24-48 $\mathrm{h}$ forecast (Fig. 13b) has higher biases extending to time periods later in the day. Components of the model were investigated to evaluate differences that may lead to the higher model bias to the eastern side of Lake Michigan. Winds tend to start the day with a northto-south median wind component, with a switch to southto-north wind component in the region of 11:00-15:00 CDT for the $1-24 \mathrm{~h}$ forecast, and an earlier at 08:00 CDT for the $25-48 \mathrm{~h}$ forecast. This difference in modeling Chicago's northward-traveling plume in the $25-48 \mathrm{~h}$ forecast may lead to the higher $\mathrm{O}_{3}$ biases for that forecast.

CMAQ developmental model biases were also determined at the Kenosha site for ozone, $\mathrm{NO}_{2}, \mathrm{SO}_{2}$ and formaldehyde (Fig. 14). Ozone was overpredicted in the model for this shoreline measurement for daylight times, with correlations lower than those obtained over water $\left(R^{2}=0.671-24 \mathrm{~h}\right.$, $\left.R^{2}=0.5825-48 \mathrm{~h}\right) . \mathrm{NO}_{2}$ is underpredicted during daylight hours, but not of the same magnitude as the overprediction 
a)
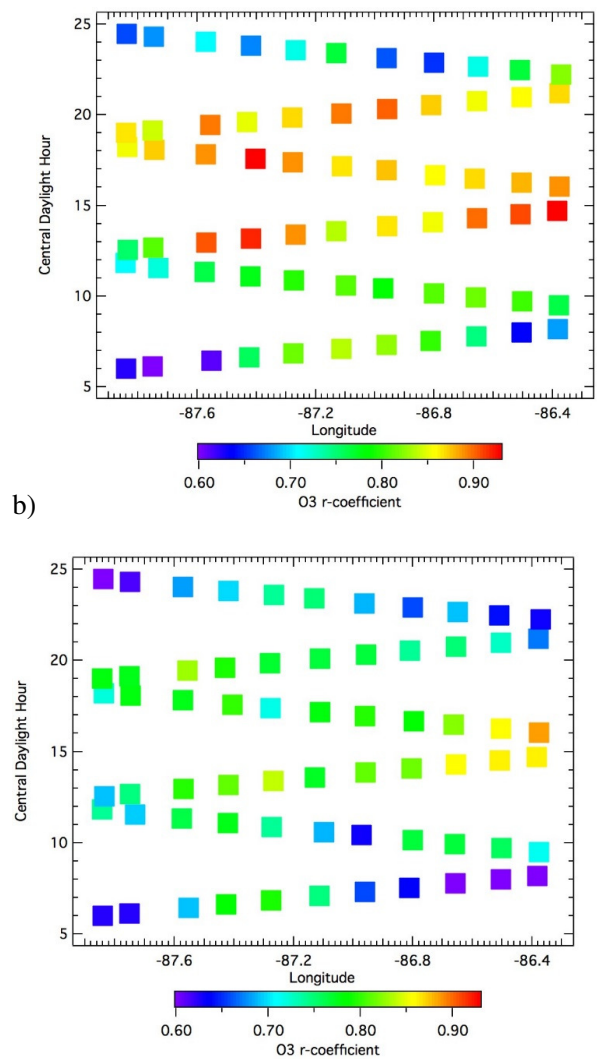

Figure 12. Correlation coefficients for model-measurement comparison for each bin; (a) 1-24h forecast, (b) 25-48 h forecast.

of ozone $\left(R^{2}=0.381-24 \mathrm{~h}, R^{2}=0.3025-48 \mathrm{~h}\right)$. Formaldehyde is consistently underpredicted when it is measured, with effectively no correlation $\left(R^{2}=0.03\right.$ for both $1-24 \mathrm{~h}$ and 25 $48 \mathrm{~h}$ forecasts). Gaps in formaldehyde bias are from gaps in formaldehyde data at the Kenosha site. Bias in $\mathrm{SO}_{2}$ show little trend with respect to time of day and little to no correlation $\left(R^{2}=0.161-24 \mathrm{~h}, R^{2}=0.1825-48 \mathrm{~h}\right)$.

The midafternoon $\mathrm{O}_{3}$ (20:00 UTC) was also determined for all EPA station monitors in the region (Fig. 15). The Lake Express ferry data were also used to obtain the bias at a similar time (12:30-15:00 CDT transect), shown in squares in Fig. 15. Note that there is an upwind bias in central in western Wisconsin of $\sim 7-8 \mathrm{ppb}$, and high biases are observed at some locations near Chicago and the northern Indiana region. The high biases in the Chicago area, and possibly northern Indiana, are likely due to high bias at low $\mathrm{O}_{3}$, where the effect of $\mathrm{O}_{3}$ titration by $\mathrm{NO}_{x}$ is not properly captured. The ferry biases are the only ones that are very high in a downwind region with a much smaller effect from local ozone titration, implying other causes such as the depth of the lake inversion or too much photochemistry in the model rather than too little titration. The high biases seen over Lake Michigan do not appear to extend strongly inland on either side of the lake.

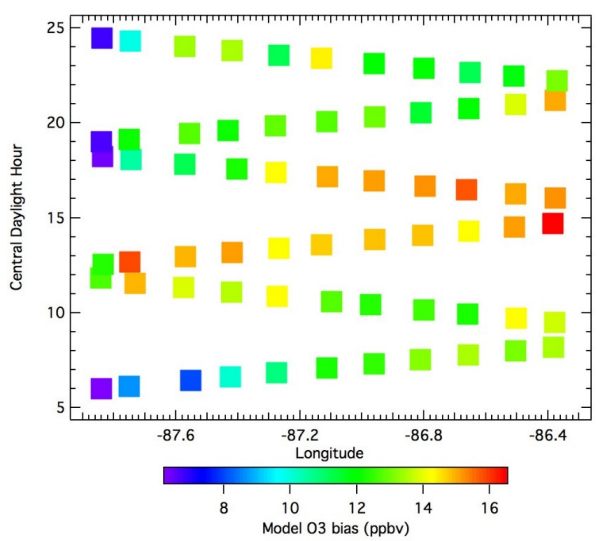

b)

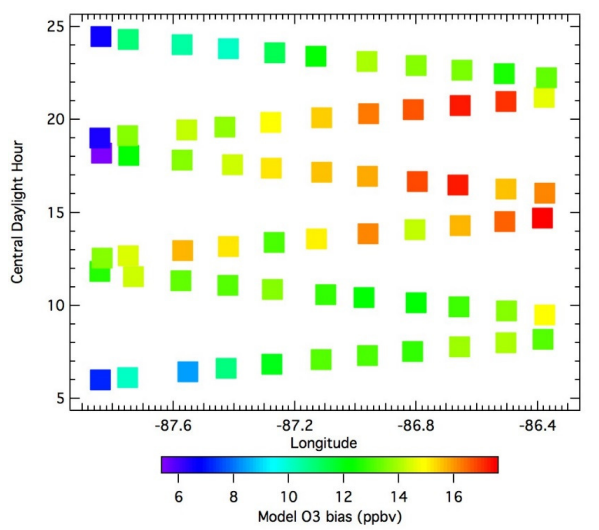

Figure 13. CMAQ model bias from (a) 1 to $24 \mathrm{~h}$ forecast and (b) 25 to $48 \mathrm{~h}$ forecast.

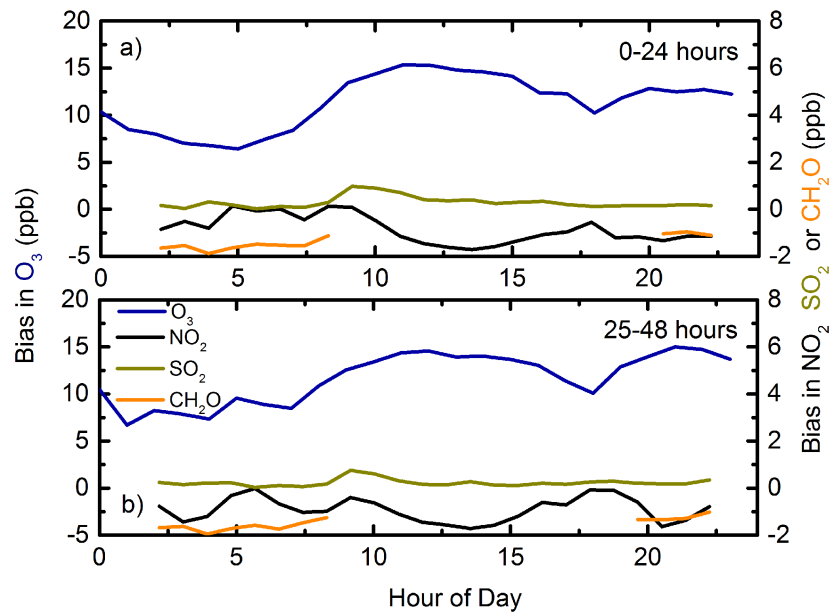

Figure 14. $\mathrm{CMAQ}$ model bias at Kenosha for $\mathrm{O}_{3}$ (in blue, left axis), $\mathrm{NO}_{2}$ (black), $\mathrm{SO}_{2}$ (brown) or formaldehyde (orange) (right axis) for (a) 1-24 $\mathrm{h}$ forecast and (b) $25-48 \mathrm{~h}$ forecast. 

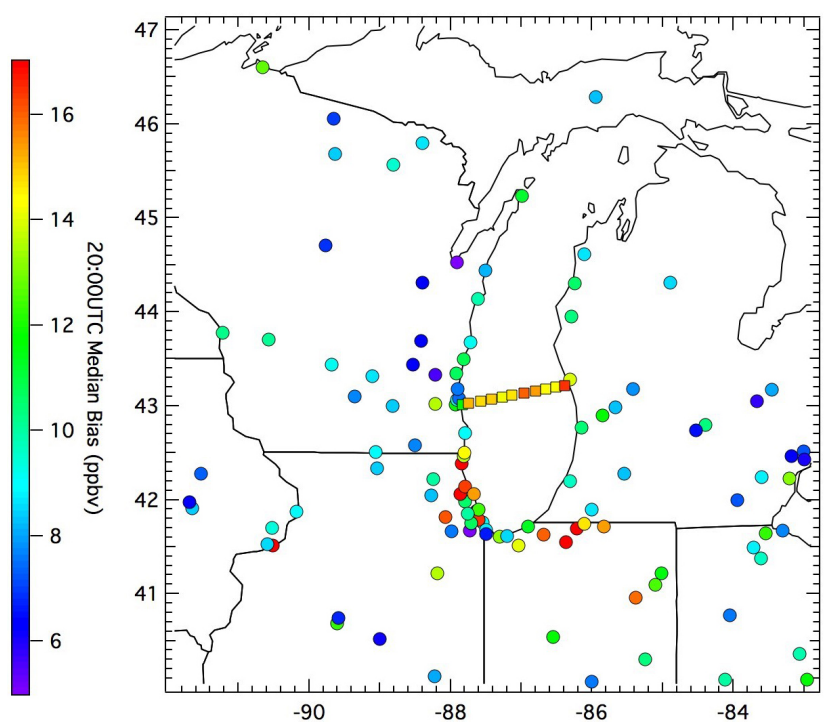

Figure 15. CMAQ model $\mathrm{O}_{3}$ bias for air quality EPA station monitors (circles) and Lake Express ferry (boxes). EPA monitor biases are calculated at 20:00 UTC (15:00 CDT), and the data have been windowed for only those days when Lake Express ferry data are available. For the Lake Express ferry data are from the 12:30 to 15:00 CDT transect statistics.

Others have also found the CMAQ to predict ozone mixing ratios that were biased high (Eder et al., 2009; Tang et al., 2009; Zhang et al., 2012a, b; Wilczak et al., 2006). Simon et al. (2012) completed an exhaustive comparison of photochemical performance statistics reported from 2006 to 2012, whereby national median in mean bias for hourly ozone was approximately $4 \mathrm{ppb}$; for $1 \mathrm{~h}$ maximum ozone it was approximately 8 ppb (Simon et al., 2012). In comparison, the bias determined in this study would be higher than the 75th percentile of studies of hourly ozone mean bias for the 40 studies compiled by Simon et al. (2012). The work presented here represents the first study of CMAQ model bias over the water of Lake Michigan and shows a higher bias than over the surrounding land.

\section{Conclusions}

Observations of shoreline $\mathrm{O}_{3}$ and ferry $\mathrm{O}_{3}$ in comparison to forecast $\mathrm{O}_{3}$ by the developmental CMAQ model show more agreement between shoreline and the ferry measurements than between ozone forecasts over the lake and ferry measurements. Shoreline Lake Michigan measurements of $\mathrm{O}_{3}$ $\mathrm{NO}_{2}, \mathrm{SO}_{2}$ and formaldehyde demonstrated the differences between onshore and offshore air masses. The comparison between ferry-based $\mathrm{O}_{3}$ observations and shoreline DOAS $\mathrm{O}_{3}$ observations indicated that diurnal changes in ozone mixing ratio were larger than spatial gradients across Lake Michigan, and ozone tended to be higher over Lake Michigan, particularly in the evening. Mesoscale meteorologic pro- cesses involving differential heating between the lake and land surfaces produced diurnal cycles of air mass flow between shoreline environments and offshore, which complicated the understanding of offshore ozone dynamics. Model forecast $\mathrm{O}_{3}$ is highly correlated with ferry monitor observations, but with afternoon median biases ranging from 11 to $16 \mathrm{ppb}$, compared to 6-9 ppb biases for land-based monitors just west of Lake Michigan. The model $\mathrm{O}_{3}$ overpredictions over water are similar to those determined for the Kenosha site, though formaldehyde and $\mathrm{NO}_{2}$ are underpredicted. The developmental CMAQ model showed a trend of increasing $\mathrm{O}_{3}$ bias to the eastern side of Lake Michigan, and a larger bias for the second-day forecast compared to the first $24 \mathrm{~h}$. Further analyses are required to determine whether CMAQ model predictions might be improved by adjusting model parameters related to emission sources, localized shoreline meteorology or atmospheric chemistry.

Acknowledgements. The authors would like to thank Kaya Sims, Lindsey Kuettner and Renee Hanson for their assistance in this experiment; the Lake Express ferry; University of Wisconsin-Eau Claire Office of Sponsored Programs Faculty and Student Collaboration Grant; Great Lakes Water Institute; Kenosha Water Utility; and the Great Lakes Observing System for their cooperation and support of this project. The authors would like to thank Bruce E. Brown for assistance with collection and calibration of ozone data from the Lake Express ferry, and Kenneth Aikin for archiving of NAQFM images. T. Langel acknowledges the NOAA Hollings Scholar Program for fellowship support during 2010. S. S. Brown acknowledges support from NOAA's Atmospheric Chemistry, Carbon Cycle and Climate Program.

Edited by: R. Cohen

\section{References}

Brown, S. S., Dibb, J. E., Stark, H., Aldener, M., Vozella, M., Whitlow, S., Williams, E. J., Lerner, B. M., Jakoubek, R., Middlebrook, A. M., DeGouw, J. A., Warneke, C., Goldan, P. D., Kuster, W. C., Angevine, W. M., Sueper, D. T., Quinn, P. K., Bates, T. S., Meagher, J. F., Fehsenfeld, F. C., and Ravishankara, A. R.: Nighttime removal of $\mathrm{NO}_{x}$ in the summer marine boundary layer, Geophys. Res. Lett., 31, doi:10.1029/2004g1019412, 2004.

Byun, D. and Schere, K. L.: Review of the governing equations, computational algorithms, and other components of the models3 Community Multiscale Air Quality (CMAQ) modeling system, Appl. Mech. Rev., 59, 51-77, doi:10.1115/1.2128636, 2006.

Carpenter, L. J., Sturges, W. T., Penkett, S. A., Liss, P. S., Alicke, B., Hebestreit, K., and Platt, U.: Short-lived alkyl iodides and bromides at Mace Head, Ireland: Links to biogenic sources and halogen oxide production, J. Geophys. Res.-Atmos., 104, 16791689, doi:10.1029/98jd02746, 1999.

Dye, T. S., Roberts, P. T., and Korc, M. E.: Observations of transport processes for ozone and ozone precursors during the 1991 Lake Michigan Ozone Study, J. Appl. Meteorol., 34, 1877-1889, 
doi:10.1175/1520-0450(1995)034<1877:ootpfo> 2.0.co;2, 1995.

Eder, B., Kang, D. W., Mathur, R., Pleim, J., Yu, S. C., Otte, T., and Pouliot, G.: A performance evaluation of the National Air Quality Forecast Capability for the summer of 2007, Atmos. Environ., 43, 2312-2320, doi:10.1016/j.atmosenv.2009.01.033, 2009.

EPA: National Air Quality Standards for Ozone; Proposed Rule, in: 40 CFR Parts 50, 51, 52, et al., 242, Federal Register, 75234754111, 2014.

Fast, J. D. and Heilman, W. E.: The effect of lake temperatures and emissions on ozone exposure in the western Great Lakes region, J. Appl. Meteorol., 42, 1197-1217, doi:10.1175/15200450(2003)042<1197:teolta>2.0.co;2, 2003.

Fast, J. D. and Heilman, W. E.: Simulated sensitivity of seasonal ozone exposure in the Great Lakes region to changes in anthropogenic emissions in the presence of interannual variability, Atmos. Environ., 39, 5291-5306, doi:10.1016/j.atmosenv.2005.05.032, 2005.

Foley, T., Betterton, E. A., Jacko, P. E. R., and Hillery, J.: Lake Michigan air quality: The 1994-2003 LADCO Aircraft Project (LAP), Atmos. Environ., 45, 3192-3202, doi:10.1016/j.atmosenv.2011.02.033, 2011.

Hanna, S. R. and Chang, J. C.: Relations between meteorology and ozone in the Lake Michigan region, J. Appl. Meteorol., 34, 670678, doi:10.1175/1520-0450(1995)034<0670:rbmaoi>2.0.co;2, 1995.

Harris, L. and Kotamarthi, V. R.: The characteristics of the Chicago Lake breeze and its effects on trace particle transport: Results from an episodic event simulation, J. Appl. Meteorol., 44, 16371654, doi:10.1175/jam2301.1, 2005.

Janjic, Z. I.: A nonhydrostatic model based on a new approach, Meteorol. Atmos. Phys., 82, 271-285, doi:10.1007/s00703-0010587-6, 2003.

Katzman, T. L., Rutter, A. P., Schauer, J. J., Lough, G. C., Kolb, C. J., and Van Klooster, S.: $\mathrm{PM}_{2.5}$ and $\mathrm{PM}_{10-2.5}$ Compositions during Wintertime Episodes of Elevated PM Concentrations across the Midwestern USA, Aerosol Air Qual. Res., 10, 140-U113, doi:10.4209/aaqr.2009.10.0063, 2010.

Keen, C. S. and Lyons, W. A.: Lake/Land Breeze circulations on the western shore of Lake Michigan, J. Appl. Meteorol., 17, 18431855, doi:10.1175/1520-0450(1978)017<1843:lbcotw>2.0.co;2, 1978.

Lennartson, G. J., and Schwartz, M. D.: A synoptic climatology of surface-level ozone in Eastern Wisconsin, USA, Climate Research, 13, 207-220, 10.3354/cr013207, 1999.

Lennartson, G. J. and Schwartz, M. D.: The lake breezeground-level ozone connection in eastern Wisconsin: A climatological perspective, Int. J. Climatol., 22, 1347-1364, doi:10.1002/joc.802, 2002.

Levy, I., Makar, P. A., Sills, D., Zhang, J., Hayden, K. L., Mihele, C., Narayan, J., Moran, M. D., Sjostedt, S., and Brook, J.: Unraveling the complex local-scale flows influencing ozone patterns in the southern Great Lakes of North America, Atmos. Chem. Phys., 10, 10895-10915, doi:10.5194/acp-1010895-2010, 2010.

Lyons, W. A. and Cole, H. S.: Photochemical oxidant transport mesoscale lake breeze and synoptic-scale aspects, J. Appl. Meteorol., 15, 733-743, 1976.
Lyons, W. A. and Olsson, L. E.: Detailed mesometeorological studies of air pollution dispersion in Chicago lake breeze, Mon. Weather Rev., 101, 387-403, 1973.

Makar, P. A., Gong, W., Mooney, C., Zhang, J., Davignon, D., Samaali, M., Moran, M. D., He, H., Tarasick, D. W., Sills, D., and Chen, J.: Dynamic adjustment of climatological ozone boundary conditions for air-quality forecasts, Atmos. Chem. Phys., 10, 8997-9015, doi:10.5194/acp-10-8997-2010, 2010.

Martin, J. C. G., Mahajan, A. S., Hay, T. D., Prados-Roman, C., Ordonez, C., MacDonald, S. M., Plane, J. M. C., Sorribas, M., Gil, M., Mora, J. F. P., Reyes, M. V. A., Oram, D. E., Leedham, E., and Saiz-Lopez, A.: Iodine chemistry in the eastern Pacific marine boundary layer, J. Geophys. Res.-Atmos., 118, 887-904, doi:10.1002/jgrd.50132, 2013.

Martinez, M., Perner, D., Hackenthal, E. M., Kulzer, S., and Schutz, L.: $\mathrm{NO}_{3}$ at Helgoland during the NORDEX campaign in October 1996, J. Geophys. Res.-Atmos., 105, 22685-22695, doi:10.1029/2000jd900255, 2000.

Pan, L., Tong, D., Lee, P., Kim, H. C., and Chai, T. F.: Assessment of $\mathrm{NO}_{x}$ and $\mathrm{O}_{3}$ forecasting performances in the US National Air Quality Forecasting Capability before and after the 2012 major emissions updates, Atmos. Environ., 95, 610-619, doi:10.1016/j.atmosenv.2014.06.020, 2014.

Pugliese, S. C., Murphy, J. G., Geddes, J. A., and Wang, J. M.: The impacts of precursor reduction and meteorology on groundlevel ozone in the Greater Toronto Area, Atmos. Chem. Phys., 14, 8197-8207, doi:10.5194/acp-14-8197-2014, 2014.

Rivera, C., Mellqvist, J., Samuelsson, J., Lefer, B., Alvarez, S., and Patel, M. R.: Quantification of $\mathrm{NO}_{2}$ and $\mathrm{SO}_{2}$ emissions from the Houston Ship Channel and Texas City industrial areas during the 2006 Texas Air Quality Study, J. Geophys. Res.-Atmos., 115, 10, doi:10.1029/2009jd012675, 2010.

Seitz, K., Buxmann, J., Pöhler, D., Sommer, T., Tschritter, J., Neary, T., O'Dowd, C., and Platt, U.: The spatial distribution of the reactive iodine species IO from simultaneous active and passive DOAS observations, Atmos. Chem. Phys., 10, 2117-2128, doi:10.5194/acp-10-2117-2010, 2010.

Sills, D. M. L., Brook, J. R., Levy, I., Makar, P. A., Zhang, J., and Taylor, P. A.: Lake breezes in the southern Great Lakes region and their influence during BAQS-Met 2007, Atmos. Chem. Phys., 11, 7955-7973, doi:10.5194/acp-11-7955-2011, 2011.

Simon, H., Baker, K. R., and Phillips, S.: Compilation and interpretation of photochemical model performance statistics published between 2006 and 2012, Atmos. Environ., 61, 124-139, doi:10.1016/j.atmosenv.2012.07.012, 2012.

Stanier, C., Singh, A., Adamski, W., Baek, J., Caughey, M., Carmichael, G., Edgerton, E., Kenski, D., Koerber, M., Oleson, J., Rohlf, T., Lee, S. R., Riemer, N., Shaw, S., Sousan, S., and Spak, S. N.: Overview of the LADCO winter nitrate study: hourly ammonia, nitric acid and $\mathrm{PM}_{2.5}$ composition at an urban and rural site pair during $\mathrm{PM}_{2.5}$ episodes in the US Great Lakes region, Atmos. Chem. Phys., 12, 11037-11056, doi:10.5194/acp12-11037-2012, 2012.

Takashima, H., Irie, H., Kanaya, Y., and Akimoto, H.: Enhanced $\mathrm{NO} 2$ at Okinawa Island, Japan caused by rapid air-mass transport from China as observed by MAX-DOAS, Atmos. Environ., 45, 2593-2597, doi:10.1016/j.atmosenv.2010.10.055, 2011.

Tang, Y. H., Lee, P., Tsidulko, M., Huang, H. C., McQueen, J. T., DiMego, G. J., Emmons, L. K., Pierce, R. B., Thompson, A. M., 
Lin, H. M., Kang, D. W., Tong, D., Yu, S. C., Mathur, R., Pleim, J. E., Otte, T. L., Pouliot, G., Young, J. O., Schere, K. L., Davidson, P. M., and Stajner, I.: The impact of chemical lateral boundary conditions on CMAQ predictions of tropospheric ozone over the continental United States, Environ. Fluid Mechan., 9, 43-58, doi:10.1007/s10652-008-9092-5, 2009.

Vrekoussis, M., Kanakidou, M., Mihalopoulos, N., Crutzen, P. J., Lelieveld, J., Perner, D., Berresheim, H., and Baboukas, E.: Role of the $\mathrm{NO}_{3}$ radicals in oxidation processes in the eastern Mediterranean troposphere during the MINOS campaign, Atmos. Chem. Phys., 4, 169-182, doi:10.5194/acp-4-169-2004, 2004.

White, M. L., Russo, R. S., Zhou, Y., Mao, H., Varner, R. K., Ambrose, J., Veres, P., Wingenter, O. W., Haase, K., Stutz, J., Talbot, R., and Sive, B. C.: Volatile organic compounds in northern New England marine and continental environments during the ICARTT 2004 campaign, J. Geophys. Res.-Atmos., 113, 16, doi:10.1029/2007jd009161, 2008.
Wilczak, J., McKeen, S., Djalalova, I., Grell, G., Peckham, S., Gong, W., Bouchet, V., Moffet, R., McHenry, J., McQueen, J., Lee, P., Tang, Y., and Carmichael, G. R.: Bias-corrected ensemble and probabilistic forecasts of surface ozone over eastern North America during the summer of 2004, J. Geophys. Res.Atmos., 111, doi:10.1029/2006jd007598, 2006.

Zhang, Y., Bocquet, M., Mallet, V., Seigneur, C., and Baklanov, A.: Real-time air quality forecasting, Part I: History, techniques, and current status, Atmos. Environ., 60, 632-655, doi:10.1016/j.atmosenv.2012.06.031, 2012a.

Zhang, Y., Bocquet, M., Mallet, V., Seigneur, C., and Baklanov, A.: Real-time air quality forecasting, Part II: State of the science, current research needs, and future prospects, Atmos. Environ., 60, 656-676, doi:10.1016/j.atmosenv.2012.02.041, 2012b. 